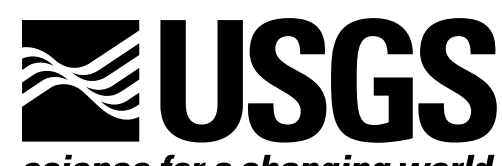

science for a changing world

\title{
Organic Petrography of Coals from a Coalbed Methane Test Well, Ouachita Parish, Louisiana
}

By Paul C. Hackley and Peter D. Warwick, USGS Reston, VA 20192

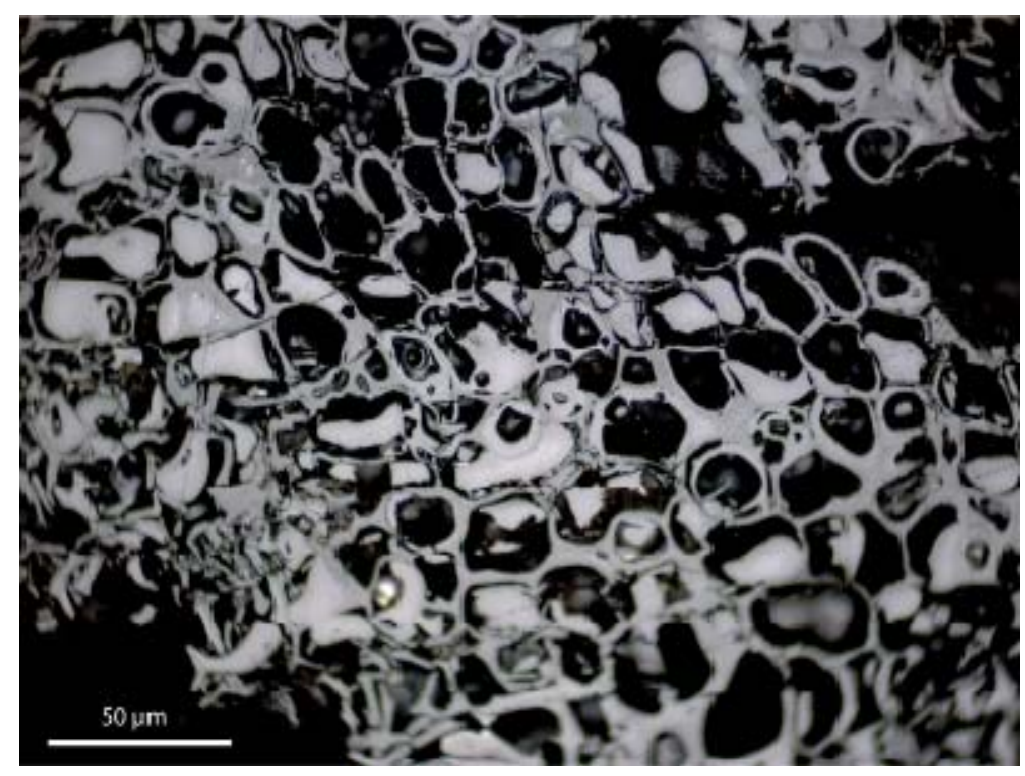

This report is preliminary and has not been reviewed for conformity with U.S. Geological Survey editorial standards and stratigraphic nomenclature. Any use of trade, product, or firm names is for descriptive purposes only, and does not imply endorsement by the U.S. Geological Survey.

Open-File Report 2005-1134

\section{U.S. Department of the Interior}

\section{U.S. Geological Survey}




\section{Organic Petrography of Coals from a Coalbed Methane Test Well, Ouachita Parish, Louisiana}

\author{
By Paul C. Hackley and Peter D. Warwick, \\ USGS Reston, VA 20192
}

\section{Introduction}

In March, 2003, the U.S. Geological Survey, the Louisiana Geological Survey, and EnerVest Management Partners Ltd., participated in a Cooperative Research and Development Agreement (CRADA) to drill and core the Fairbanks Real Estate No. 359 (FRE No. 359) coalbed methane test well in Ouachita Parish, Louisiana (fig. 1) (Warwick and others, 2004a). This effort was in support of ongoing U.S. Geological Survey investigations into the coal gas potential of the Gulf Coastal Plain. To determine possible relationships between coalbed gas content and coal composition, maceral modes were determined for 17 subsurface coal and carbonaceous shale samples cored and desorbed from the Paleocene-Eocene Wilcox Group (fig. 2). Similar determinations of maceral mode were made on cuttings collected from 5 non-cored coaly intervals in the overlying Eocene Sparta Sand.

\section{Subsurface Coal Geology}

Coals targeted for gas potential in the subsurface of northern Louisiana occur in the lower Wilcox Group (Paleocene-Eocene) at depths of 1,310-4,920 ft (400$1,500 \mathrm{~m})$, where individual coal beds reach a maximum thickness of up to $20 \mathrm{ft}(6 \mathrm{~m})$ and a cumulative thickness of up to $100 \mathrm{ft}(30 \mathrm{~m}$ ) (Breland, 2004; Warwick and others, 2004b). Subsurface studies based on electric and induction-resistivity logs from oil and gas exploration (Coates, 1979; Coates and others, 1980; Ledoux, 1982; Rogers, 1983) identified up to 35 individual coal beds in the lower Wilcox. Correlative coal beds at the surface in northwestern Louisiana and eastern Texas on the Sabine Uplift are lignite in rank (Barker and others, 2000). In the northern Louisiana subsurface, coal rank increases to subbituminous B (Warwick and others, 2004b). Previous studies suggest that the coals were deposited in stacked interdistributary environments on a progradational fluvial-deltaic plain (Holly Springs delta complex) influenced by the positive structural elements of the Monroe Uplift to the northeast and the Sabine Uplift to the northwest (fig. 1) (Ayers and Lewis, 1985; Kaiser, 1990; Echols, 2001; Scott, 2003). The Monroe Uplift, on which the FRE No. 359 test well is located, is a broad subsurface dome of Tertiary and Upper Cretaceous strata occurring over northern Louisiana, southern Arkansas, and western Mississippi, and it constitutes one of the major structural features of the Gulf Coastal Plain (Ewing, 1991). Vertical uplift is thought to be related to the emplacement of Late Cretaceous alkalic igneous rocks, and the area is characterized by relatively high heat flux compared to other areas of the eastern Gulf Coastal Plain (Smith and Dees, 1982).

\section{Coal Samples}

The FRE No. 359 well was drilled to a total depth of 1,628 ft (496 m) in March, 2003 (Warwick and others, 2004a). Coal core samples were recovered from four coaly zones in the lower Wilcox Group (fig. 3 and Table 1) at depths of 1,329-1,334.8 ft (405.1-406.8 m) (zone 1); 1,498-1,499.25 ft (456.6-456.9 m) (zone 2; includes carbonaceous shale); zone 3: 1,515.25-

1,517.5 ft (461.8-462.4 m) (zone 3); and 1,574-1,581.2 $\mathrm{ft}(479.8-481.9 \mathrm{~m}$ ) (zone 4). Including a stray coal at 1,563.8-1,564.5 ft (476.6-476.8 m), a total of $12.75 \mathrm{ft}$ $(3.9 \mathrm{~m})$ of coal was recovered from the FRE No. 359 well. Coal cuttings were collected from the overlying Sparta Sand at the five intervals of 390-400 ft (118.9$121.9 \mathrm{~m}), 420-430 \mathrm{ft}(128.0-131.1 \mathrm{~m}), 540-550 \mathrm{ft}$ (164.6-170.7 m), 650-660 ft (198.1-201.2 m), and 720$730 \mathrm{ft}$ (219.5-219.6 m).

Coal zone 1 in the Wilcox is composed of $5.8 \mathrm{ft}$ $(1.77 \mathrm{~m})$ of coal with no partings. This coal zone 
overlies carbonaceous shale and shaly claystone that show no signs of rooting. The coal zone is succeeded by dark gray carbonaceous shale and bioturbated siltstone and shaly claystone.

Samples from coal zone 2 consist of an upper coal bench of $0.9 \mathrm{ft}(0.27 \mathrm{~m})$ thickness and a lower bench of carbonaceous shale (53.29 weight percent [wt.\%] ash) of $0.36 \mathrm{ft}(0.11 \mathrm{~m})$ thickness. This coal zone is underlain by dark gray silty shale with sandy streaks and there are no indications of rooting below the coal bench. The coal zone is succeeded by dark gray shaly siltstone.

Three samples from coal zone 3 consist of an upper coal bench of $0.25 \mathrm{ft}(0.08 \mathrm{~m})$ thickness underlain by a $0.5 \mathrm{ft}(0.15 \mathrm{~m})$ parting (not sampled) composed of thinly interlayered coal and rock. Two bench coal samples from beneath the parting have a total thickness of $1.5 \mathrm{ft}(0.46 \mathrm{~m})$. Dark gray claystone underlying coal zone 3 is rooted, and dark gray silty shale overlying the zone contains sandstone streaks and burrow.

At a depth of 1,563.7 ft (476.6 m) below surface, a thin impure coal (44.54 wt. \% ash) of $0.75 \mathrm{ft}(0.23 \mathrm{~m})$ thickness (sample LA-03-CB3-48) is underlain by dark gray rooted claystone and succeeded by dark gray bioturbated shaly claystone.

The deepest coal zone (coal zone 4) at 1,5741,581.2 ft (479.8-481.9 m) consists of 5 bench coal samples separated by 2 partings and has an aggregate thickness of $6.2 \mathrm{ft}(1.89 \mathrm{~m})$. The uppermost bench coal sample of $0.9 \mathrm{ft}(0.27 \mathrm{~m})$ thickness is underlain by $0.9 \mathrm{ft}(0.27 \mathrm{~m})$ of dark gray shaly claystone. Underlying this parting is $2 \mathrm{ft}(0.61 \mathrm{~m})$ of coal divided into two bench samples which are in turn underlain by $1.4 \mathrm{ft}(0.43 \mathrm{~m})$ of dark gray carbonaceous shale. The base of coal zone 4 consists of another $2 \mathrm{ft}$ $(0.61 \mathrm{~m})$ coal thickness divided into two bench samples. Underlying coal zone 4 is dark gray rooted siltstone. The overlying $3.1 \mathrm{ft}(0.94 \mathrm{~m})$ of core was lost during retrieval.

\section{Methodology}

For petrographic analyses, samples were ground to pass -16 mesh, cast in epoxy, and polished following the procedures outlined in Pontolillo and Stanton (1994). Two sample mounts were made from each sample. Measurement of maximum huminite reflectance in immersion oil $\left(R_{\max }\right)$ was performed according to the ASTM D2798 protocol (ASTM, 2002).

Following measurement of maximum reflectance, samples were examined in blue-light fluorescence by a modification of ASTM D2799 (ASTM, 2002). Identifications of liptinite or non-fluorescing organic/mineral matter were made at 500 points on each sample mount. Following the blue light point count, identifications of huminite and inertinite macerals were made at 500 points on each mount under oil immersion in white light, for a total of 2000 counts per sample. Identification of coal macerals follows the nomenclature proposed by the International Committee for Coal and Organic Petrology (ICCP System 1994) (ICCP, 2001; Sýkorová and others, 2005) for the inertinite and huminite macerals, respectively, and of Taylor and others (1998) for the liptinite macerals.

Volume percent mineral matter of the desorbed Wilcox coal samples was calculated from measured parameters using $\mathrm{SO}_{3}$-free ash and true specific gravity according to ASTM D2799 (ASTM, 2002). Volume percent mineral matter content of the Sparta cuttings was determined by point count in white light.

\section{Results}

Reflectance

Maximum reflectance of ulminite $B$ in immersion oil was found to vary minimally down-hole across the range of $0.22-0.39 \%$ (Table 2 and Table 3; fig. 4). The low value in sample LA-03-CB3-8 (0.22 \%) is significantly suppressed relative to the other samples (Table 2). Due to high mineral matter content, huminite was relatively difficult to find in this sample. For this reason, and because there was enough sample to prepare only one mount, 21 determinations of $R_{\max }$ were made, rather than the preferred number of 100 (ASTM, 2002). Despite the low number of measurements, standard deviation $( \pm 0.05 \%)$ in the measured value of $0.22 \%$ is similar to the standard deviation in the measurement of $\mathrm{R}_{\max }$ for other samples. Suppression of $\mathrm{R}_{\max }$ by bitumen impregnation is unlikely as this sample contains only 1 vol.\% total liptinite. The anomalously low value may be influenced by high mineral matter content (55 
vol.\%). Excluding this sample, $\mathrm{R}_{\max }$ varies across the range $0.29-0.39 \%$. Typical values of standard deviation are on the order of $\pm 0.04 \%$. Reflectance is invariant with respect to depth $\left(r^{2}=0.08\right)$.

\section{Organic Petrography of Wilcox Samples}

The Wilcox coal samples are dominated by huminite group macerals (fig. 5). Abundance of total huminite ranges from 74-90 vol.\% (Table 2) on a mineral-matter-free (mmf) basis. Total liptinite content (1-20 vol.\% mmf) typically is higher than inertinite (2-15 vol. \% mmf). Excluding the carbonaceous shale sample LA-03-CB3-8 (1 vol.\% liptinite), liptinite content in the 16 Wilcox coal samples averages 10.9 vol. \% mmf. Concentrations of huminite show a consistent decrease upwards in each coal bed (fig. 5), accompanied by a corresponding increase in the concentration of liptinite or inertinite, or both.

Huminite in the Wilcox samples is represented almost entirely by ulminite (fig. 6) and attrinite (fig. 7). Concentrations of the other point-counted huminite group macerals, densinite, corpohuminite (fig. 7A), phlobaphinite (fig. 8A), and textinite, typically make up $<5$ vol. $\%$ of the coal samples. Huminite content in the carbonaceous shale sample, LA-03-CB3-8, is represented by approximately equal portions of attrinite and huminite.

Inertinite group macerals in the Wilcox samples are more diverse in concentration than huminite. Total concentrations of macrinite, inertodetrinite (fig. 7B), fusinite (fig. 8B), semifusinite, and funginite (fig. $9 \mathrm{~A}$ and fig. 9B) range from 2-15 vol.\%. Most samples contain approximately equal portions of macrinite, fusinite, and inertodetrinite, and several samples contain significant amounts of semifusinite. Funginite is present in concentrations of $<1 \mathrm{vol} . \%$ in all samples except the carbonaceous shale sample LA-03-CB3-8, where it is not present.

Liptinite content of the Wilcox samples is composed of the structured maceral varieties sporinite (fig. 10A and fig. 10B), alginite, cutinite (fig $11 \mathrm{~A})$, and in situ resinite; detrital maceral varieties liptodetrinite (fig. 10B) and detrita/ resinite (fig. 11B); and amorphous maceral varieties bituminite and exsudatinite. In most cases, liptodetrinite dominates the liptinite group, ranging in concentration from $<1$ $10 \mathrm{vol} . \%$. The structured liptinite maceral suberinite (cork) is absent in all of the coal samples.

Absence of suberinite and relatively infrequent occurrence of textinite is inferred to indicate an overall low degree of preservation of plant tissue in all of the coal beds. Dominance of ulminite over textinite indicates generally aerobic peat-forming conditions that enabled bacterial degradation of wood cellular material into humic gels. Terpene resinite, possibly from conifers, is observed in situ in low abundances in several samples; however, detrital resinite, of which a terpene or lipid origin is indeterminate, predominates.

\section{Organic Petrography of Sparta Samples}

Total huminite in the Sparta samples ranges from 73-93 vol.\% mmf (Table 3). Attrinite constitutes the bulk of the huminite fraction in the 3 samples with highest mineral matter content; ulminite occurs in greater concentrations than attrinite only in the sample with the lowest amount of mineral matter.

Inertinite is essentially absent in the Sparta samples, occurring in amounts of $<1 \mathrm{vol} . \% \mathrm{mmf}$. These levels contrast sharply with the Wilcox samples, where inertinite ranges from 2-15 vol.\% mmf and averages 7 vol.\%. The most commonly occurring inertinite maceral in the Sparta samples is funginite, also in contrast to the Wilcox samples, where funginite is the least common inertinite maceral.

Liptinite is present in concentrations of 6-24 vol.\% $\mathrm{mmf}$ and is dominated by detrital resinite and liptodetrinite. Sporinite also is common in the two deeper samples with high mineral matter content. The total concentration of liptinite macerals in the Sparta samples is strongly related to mineral matter content $\left(r^{2}=0.86\right)$. As with the Wilcox samples, suberinite is absent.

\section{Conclusions}

Maceral composition of subsurface coal samples from northern Louisiana is similar to that reported for shallow, mineable coals of the Gulf Coast region (e.g., Mukhopadhyay, 1989). Coal samples are dominated by huminite group macerals (74-90 vol.\%), followed by 
liptinite (1-20 vol.\%), and inertinite (2-15 vol.\%). These maceral concentration data will be used in ongoing studies of regional coal gas potential to investigate possible relationships between coal type and gas content.

\section{Acknowledgments}

The authors would like to thank Sharon Swanson and Jim Coleman of the U.S. Geological Survey and Deolinda Flores of the University of Porto, Portugal, for reviews which improved the quality and clarity of this paper. The U.S. Geological Survey acknowledges the cooperation of the Louisiana Geological Survey and EnerVest Management Partners Ltd. that has led to a better understanding of the coal gas potential of the north-central Gulf Coast region.

\section{References}

ASTM, 2002, Annual book of ASTM standards:

Petroleum products, lubricants, and fossil fuels; Gaseous fuels; coal and coke, sec. 5, v. 5.06: ASTM International, West Conshohocken, PA, 650 pp.

Ayers, W.B., Jr., and Lewis, A.H., 1985, The Wilcox Group and Carrizo Sand (Paleogene) in eastcentral Texas: Depositional systems and deepbasin lignite: The University of Texas at Austin, Bureau of Economic Geology Special Publication, $19 \mathrm{pp}$.

Barker, C.E., Biewick, L.R.H., Warwick, P.D., and SanFilipo, J.R., 2000, Preliminary Gulf Coast coalbed methane exploration maps: Depth to Wilcox, apparent Wilcox thickness and vitrinite reflectance: U.S. Geological Survey Open-File Report 00-0113, 2 sheets, http://pubs. usgs.gov/of/2000/ofr-00-0113/.

Breland, F.C., Jr., 2004, Coalbed methane potential in Louisiana, in Warwick, P.D., (ed.), Selected presentations on coal-bed gas in the eastern United States: U.S. Geological Survey Open-File Report 2004-1273, pp. 27-35, http://pubs.usgs.gov/of/2004/1273/20041273Breland.pdf.

Coates, E.J., 1979, The occurrence of Wilcox lignite in west-central Louisiana: M.S. Thesis, Louisiana State University, Baton Rouge, Louisiana, 249 pp.
Coates, E.J., Groat, C.G., and Hart, G.F., 1980, Subsurface Wilcox lignite in west-central Louisiana: Gulf Coast Association of Geological Societies Transactions, v. 30, pp. 309-332.

Echols, J.B., 2001, The producibility of coalbed methane from Wilcox coals in Louisiana: Gulf Coast Association of Geological Societies Transactions, v. 51, pp. 75-84.

Ewing, T.E., 1991, Structural framework, in Salvador, A. (ed.), The Gulf of Mexico basin: Geological Society of America, The Geology of North America, v. J, pp. 31-52.

Hackley, P.C., and Warwick, P.D., 2004, Organic petrology and coal-bed gas content, deep-basin Gulf Coast coals, northern Louisiana: Geological Society of America Abstracts with Programs, v. 36, no. 5, p. 84 , http://gsa.confex.com/gsa/2004AM/finalprogram /abstract_78954.htm.

ICCP, 2001, The new inertinite classification (ICCP System 1994): Fuel, v. 80, pp. 459-471.

Kaiser, W.R., 1990, The Wilcox Group (PaleoceneEocene) in the Sabine Uplift area, Texas: depositional systems and deep-basin lignite: The University of Texas at Austin, Bureau of Economic Geology Special Publication, 20 pp.

Ledoux, J.H., 1982, Sand body geometry and the occurrence of lignite in the Wilcox of northeast Louisiana: M.S. Thesis, Northeast Louisiana University, Monroe, Louisiana, 236 pp.

Mukhopadhyay, P.K., 1989, Organic petrography and organic geochemistry of Texas Tertiary coals in relation to depositional environment and hydrocarbon generation: The University of Texas at Austin Bureau of Economic Geology Report of Investigations 188, $118 \mathrm{pp}$.

Pontolillo, J., and Stanton, R.W., 1994, Coal petrographic laboratory procedures and safety manual II: U.S. Geological Survey Open-File Report 94-361, 69 pp.

Rogers, J.D., 1983, The occurrence of deep basin lignite in the Wilcox Group of northeast Louisiana: M.S. Thesis, Louisiana State University, Baton Rouge, Louisiana, $165 \mathrm{pp}$.

Scott, A.R., 2003, Coalbed methane potential of the Gulf Coast region, in Silverman M.R., (ed.), 
Emerging coalbed methane plays of North

America, Part 2: Petroleum Frontiers, v. 18, pp. 3846.

Smith, D.L., and Dees, W.T., 1982, Heat flow in the Gulf Coastal Plain: Journal of Geophysical Research, v. 87, pp. 7687-7693.

Sýkorová, l., Pickel, W., Christanis, K., Wolf, M., Taylor, G.H., and Flores, D., 2005, Classification of huminite-ICCP System 1994: International Journal of Coal Geology, v. 62, pp. 85-106.

Taylor, G.H., Teichmüller, Davis, A., Diessel, C.F.K., Littke, R., and Robert, P., 1998. Organic Petrology. Gerbrüder Borntraeger, Berlin, 704 pp.

Warwick, P.D., Breland, F.C., Jr., Clark, A.C., and Willett, J.C., 2004a, Preliminary results from coalbed methane drilling in Ouachita Parish, Louisiana: U.S. Geological Survey Open-File Report 2004-1239, 3 pp, http://pubs.usgs.gov/of/2004/1239/.
Warwick, P.D, Breland, F.C., Jr., Ratchford, M.E. and Hackley, P.C., 2004b, Coal gas resource potential of Cretaceous and Paleogene coals of the Gulf of Mexico Coastal Plain (including a review of the activity in the Appalachian and Warrior basins), in Warwick, P.D., (ed.), Selected presentations on coal-bed gas in the eastern United States: U.S. Geological Survey Open File Report 2004-1273, pp. 1-25,

http://pubs.usgs.gov/of/2004/1273/20041273Warwick.pdf.

Warwick, P. D., SanFilipo, J. R., Crowley, S. S., Thomas, R. E., and Fried, J., compilers; Tully, J. K., digital compiler, 1997, Map showing outcrop of the coal-bearing units and land use in the Gulf Coast coal region: U.S. Geological Survey OpenFile Report 97-172, scale 1:2,000,000, http://pubs.usgs.gov/of/1997/of97-172/. 


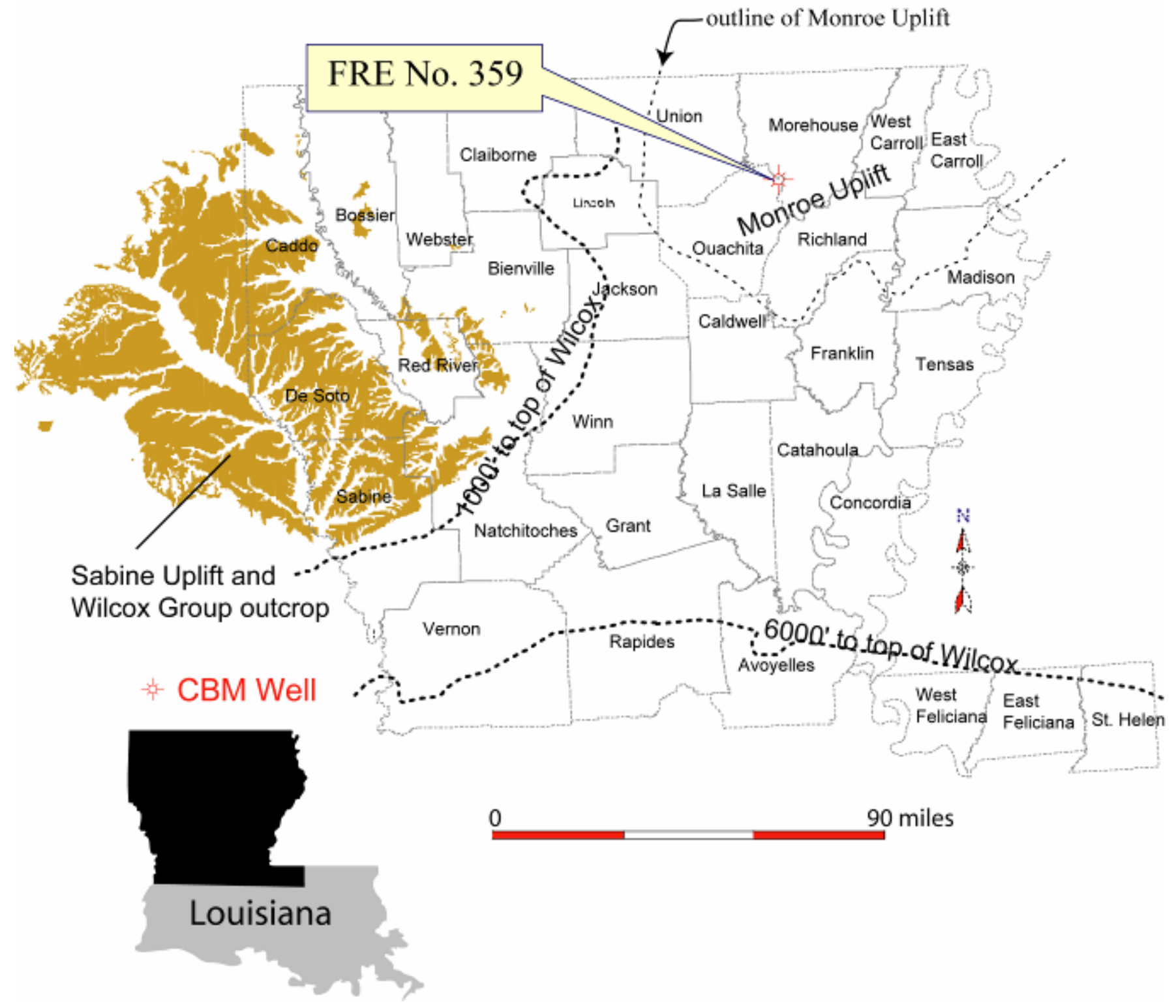

Figure 1. Location of FRE No. 359 methane test well in northeastern Ouachita Parish, Louisiana. Heavy dotted lines indicate estimated depths (1000 ft and $6000 \mathrm{ft}$ ) to the top of the Wilcox Group. Modified from Warwick and others (2004b). 


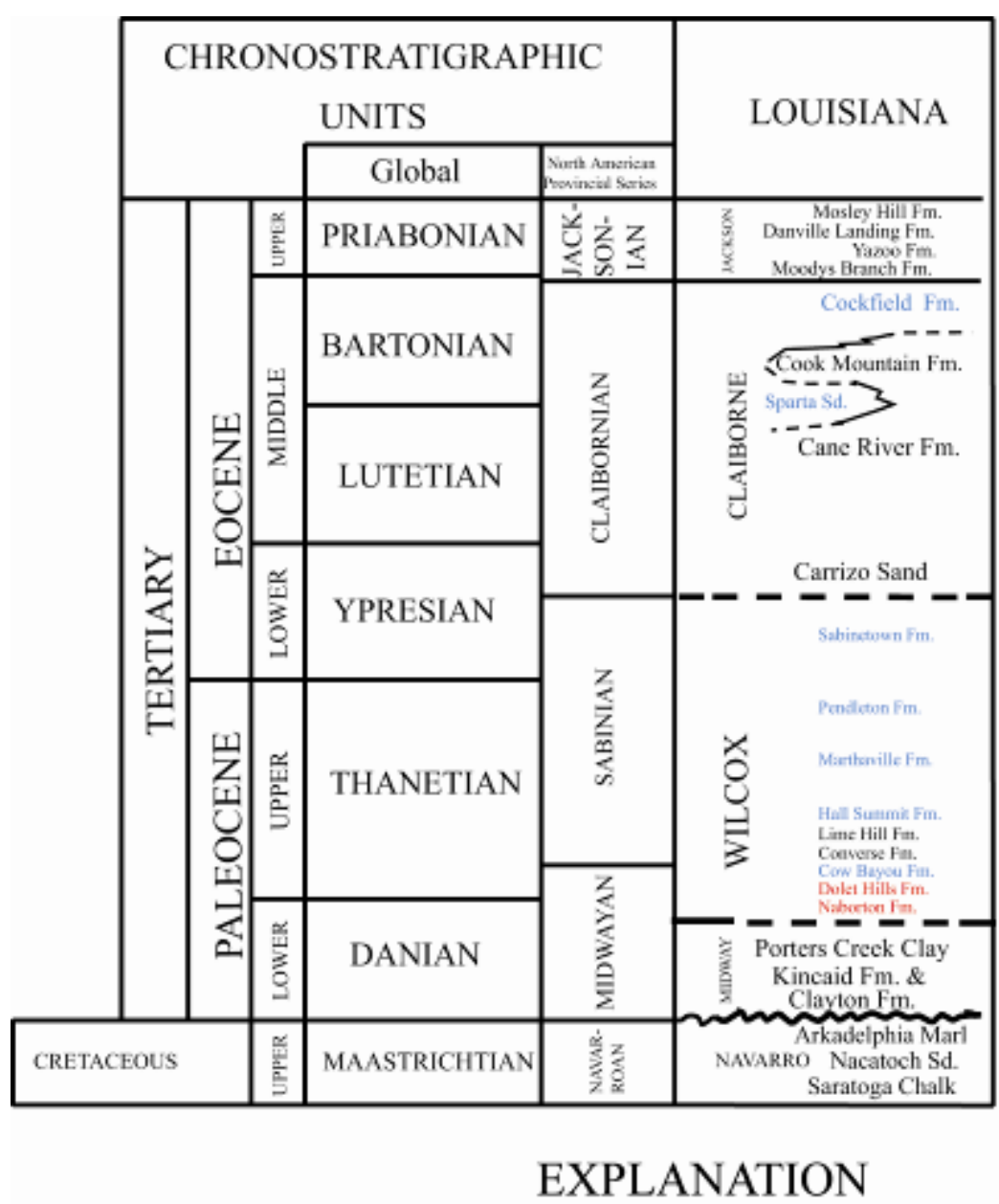

WILCOX Group name

CONTACTS

Carrizo Sand Formation name

Conformable

name in red Major coal-bearing formation (or group, where shown undivided)

Disconformable

Uncertain

name in blue Minor coal-bearing formation

Figure 2. Generalized stratigraphic column for the Upper Cretaceous to Eocene strata of Louisiana. Modified from Warwick and others (1997). Abbreviations: Fm.=Formation, Sd.=Sand. 


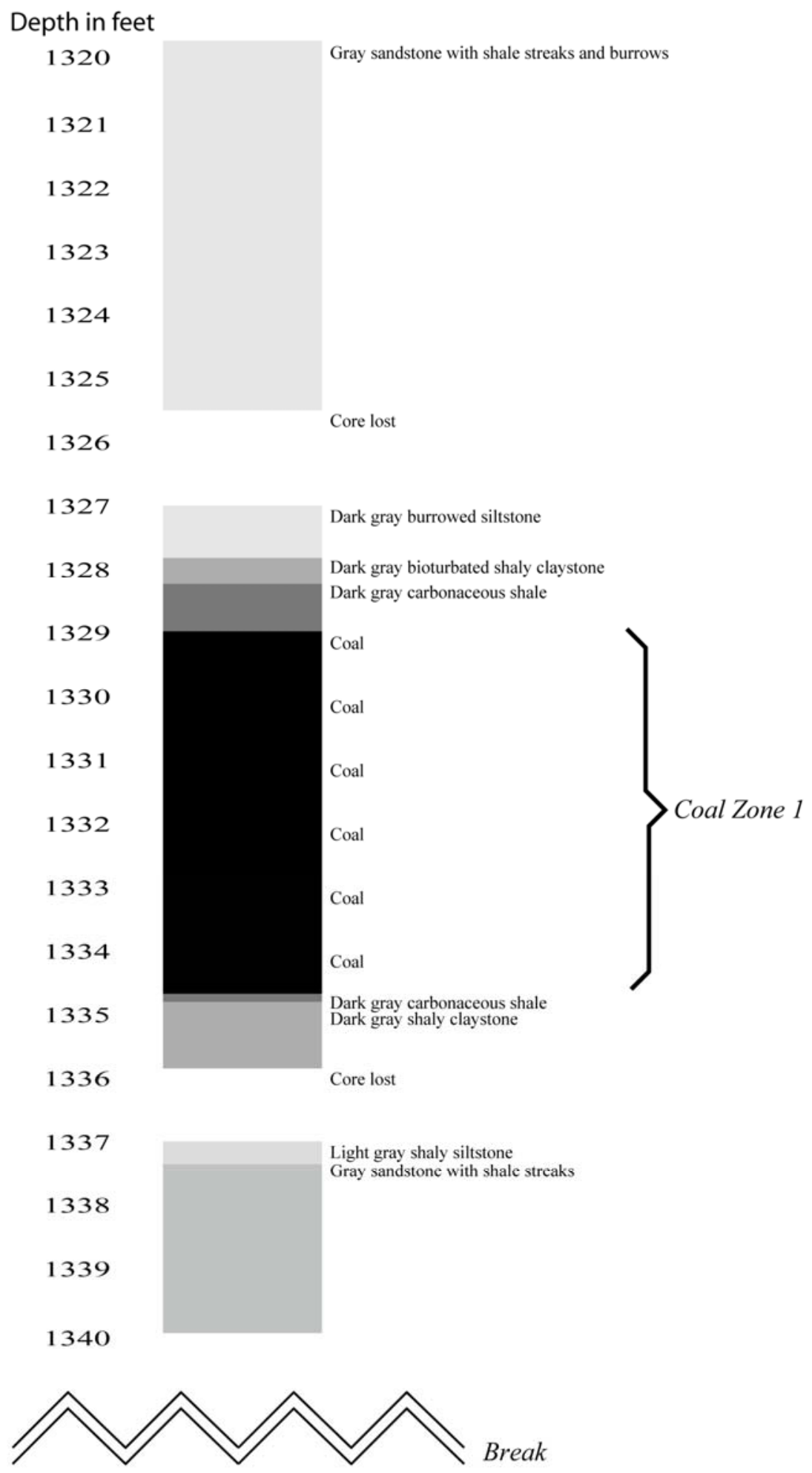

Figure 3. Simplified Wilcox stratigraphy of FRE No. 359 coalbed methane test well (1320-1340'). Depths in feet. 


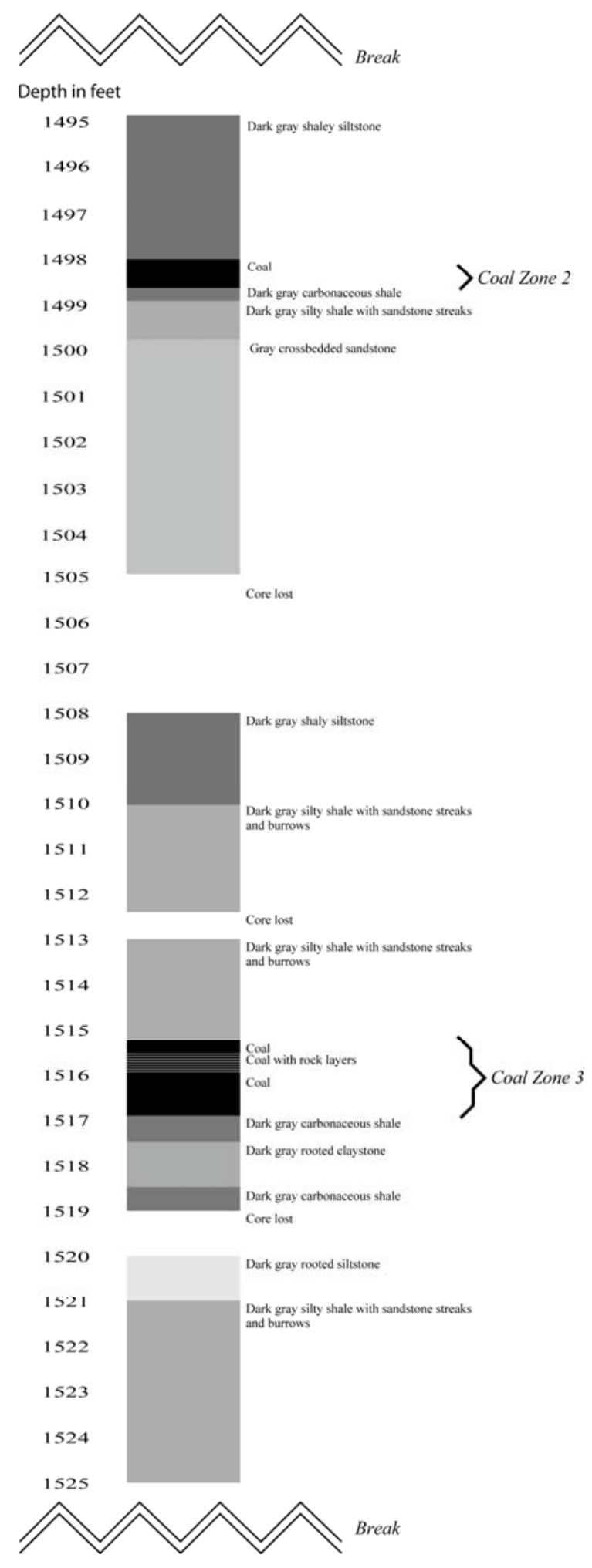

Figure 3 continued. Simplified Wilcox stratigraphy of FRE No. 359 coalbed methane test well (1495-1525'). Depths in feet. 


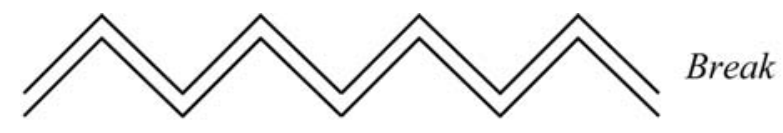

\section{Depth in feet}

1568

1569

Dark gray rooted claystone

1570

1571

Core lost

1572

1573

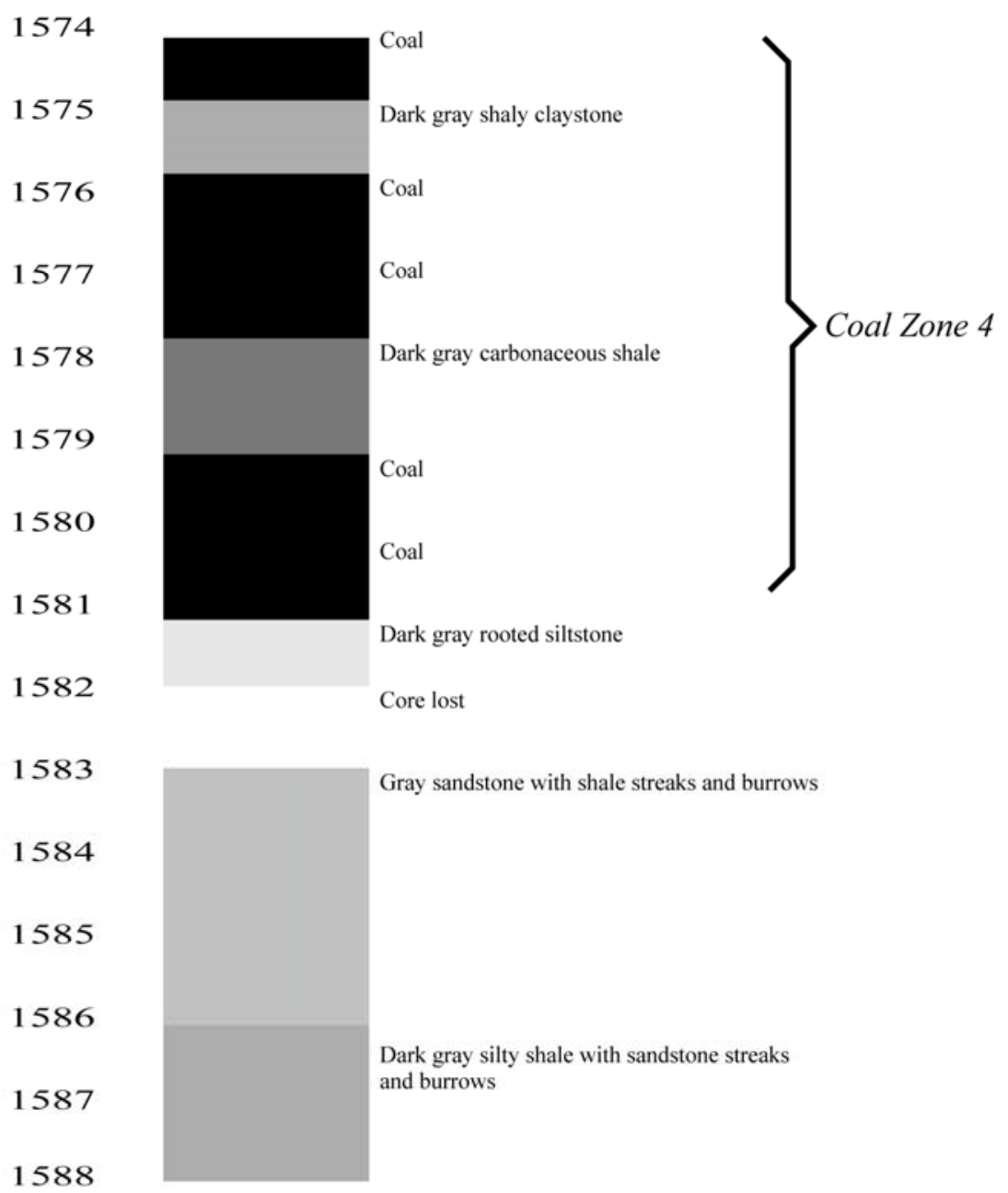

Figure 3 continued. Simplified Wilcox stratigraphy of FRE No. 359 coalbed methane test well (1568-1588'). Depths in feet. 


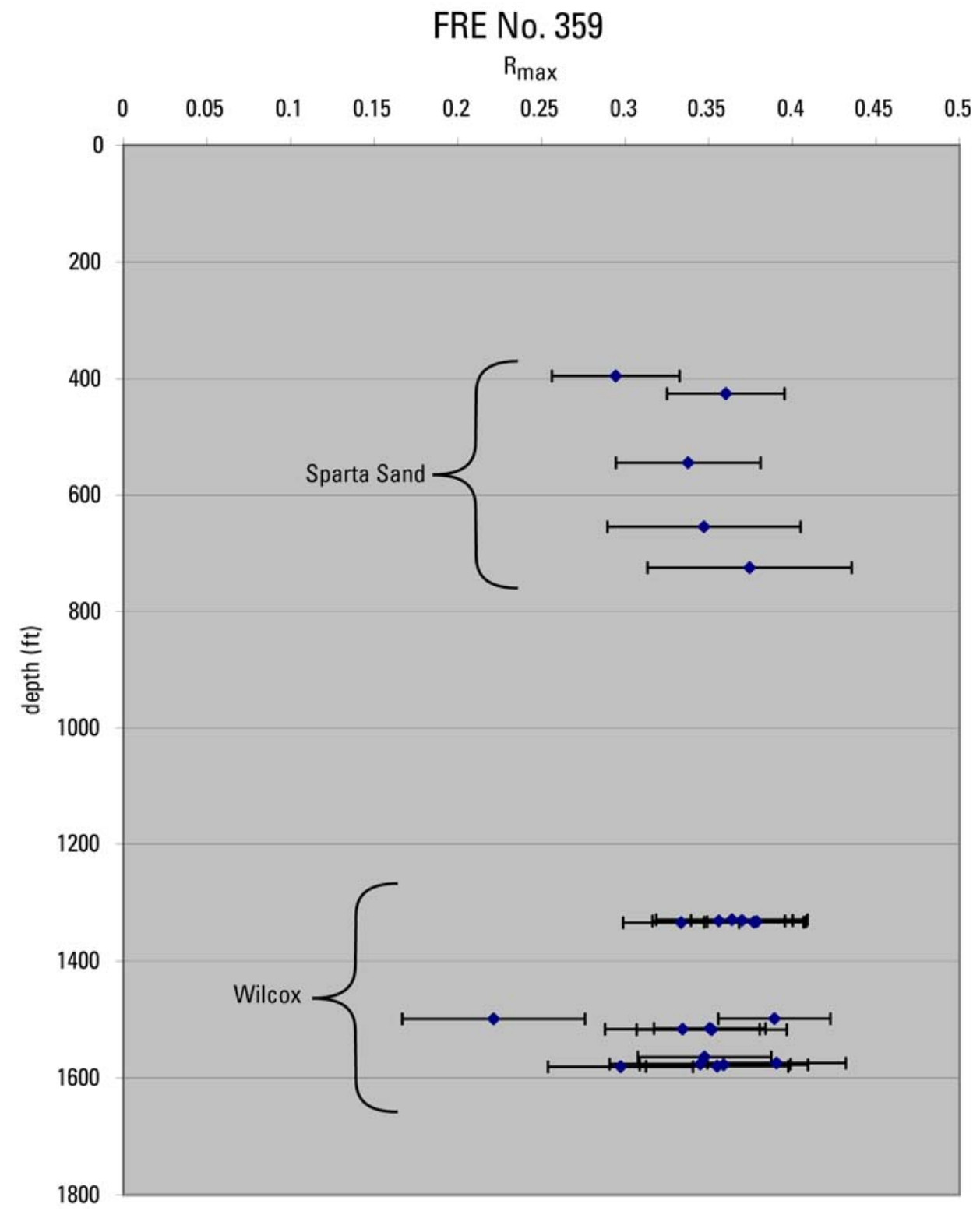

Figure 4. Maximum reflectance of ulminite B versus depth in the FRE No. 359 methane test well. Error bars indicate $+/$ - one standard deviation. 


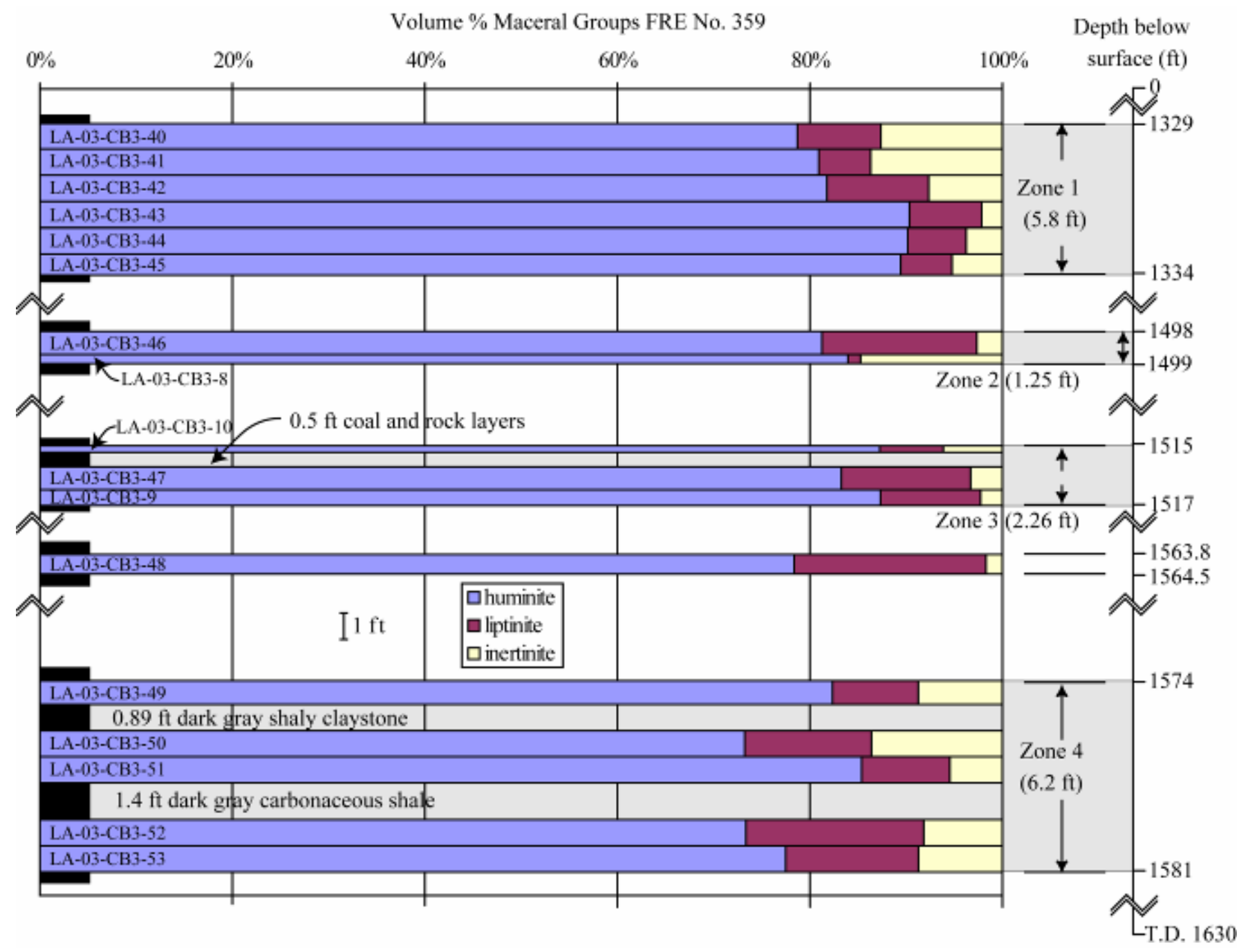

Figure 5. Volume percent maceral groups in the Wilcox FRE No. 359 coal samples. 

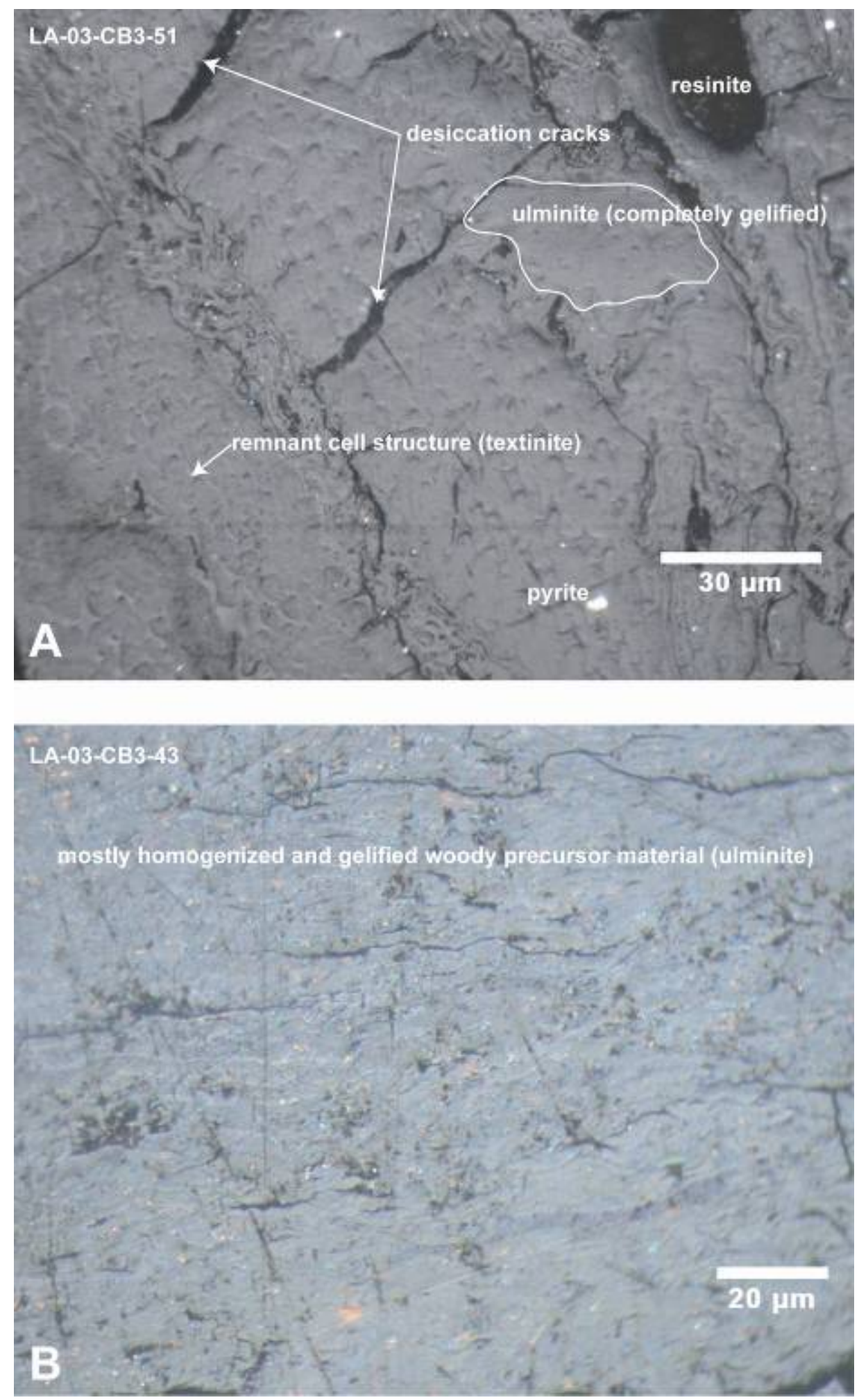

Figure 6. (A) Ulminite in sample LA-03-CB3-51, oil immersion, reflected white light, (B) Ulminite in sample LA-03CB3-43, oil immersion, reflected white light. 

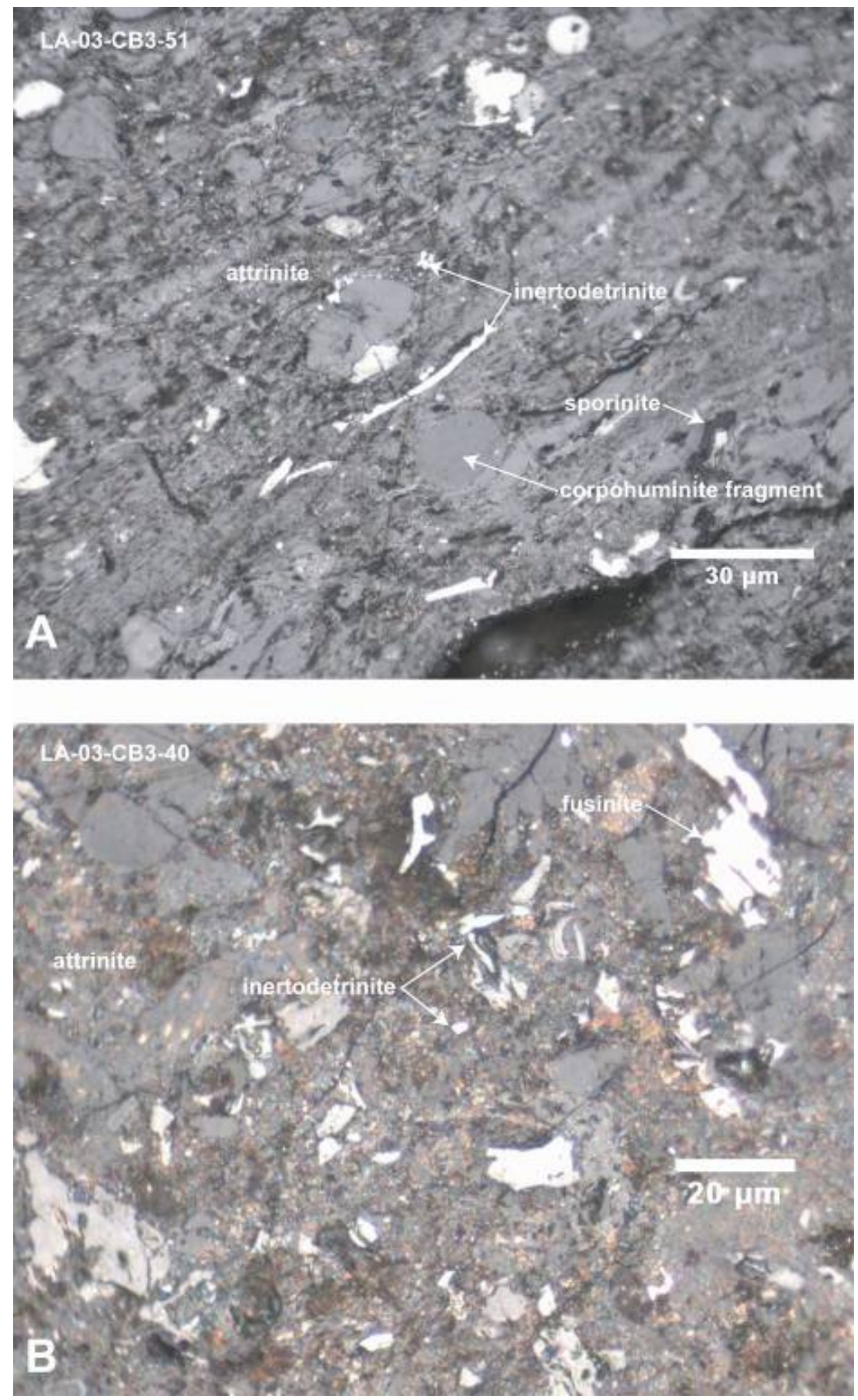

Figure 7. (A) Attrinite in sample LA-03-CB3-51, oil immersion, reflected white light, (B) Attrinite in sample LA-03CB3-40, oil immersion, reflected white light. 

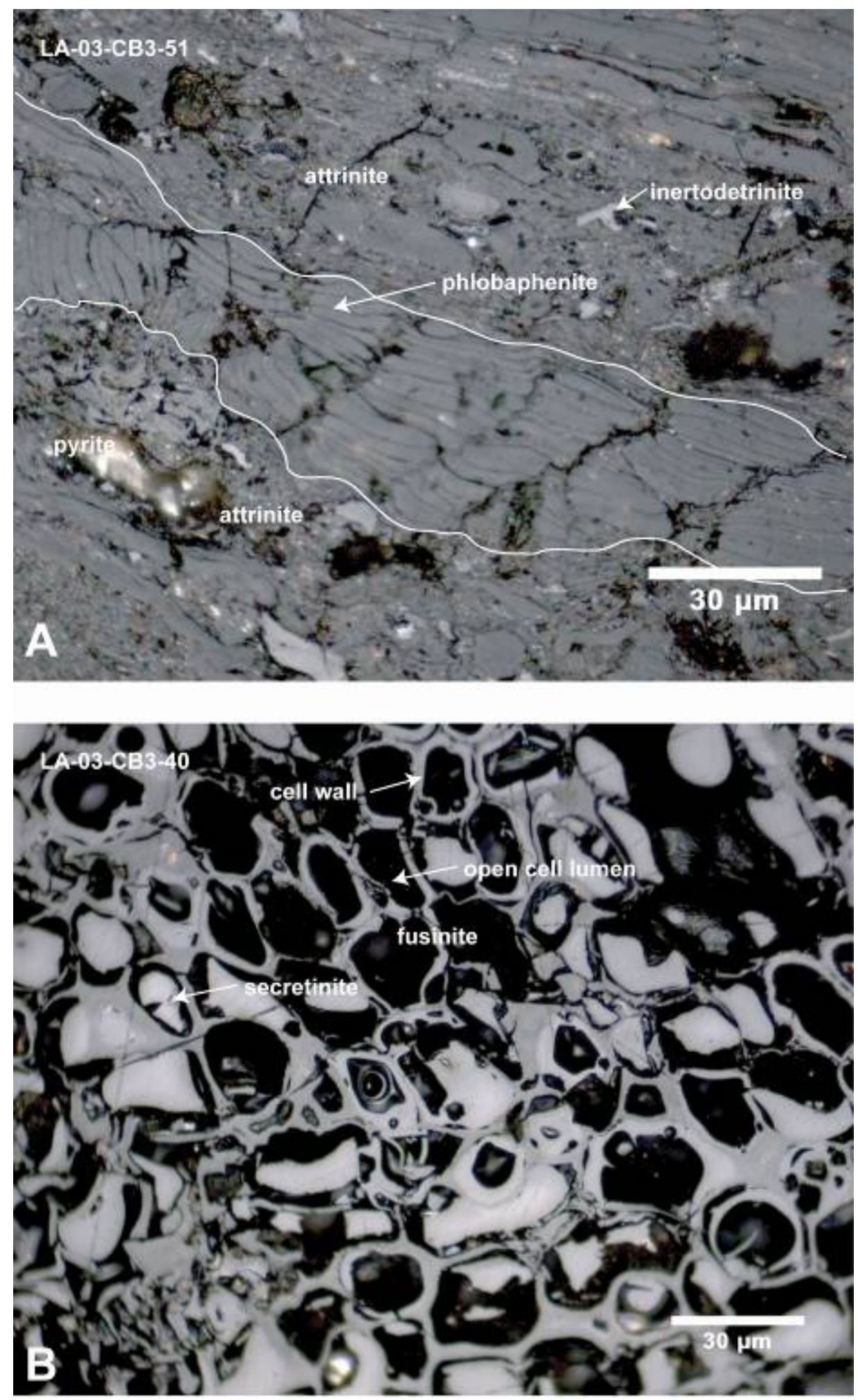

Figure 8. (A) Phlobaphinite and attrinite in sample LA-03-CB3-51, oil immersion, reflected white light, (B) Fusinite in sample LA-03-CB3-40, oil immersion, reflected white light. 

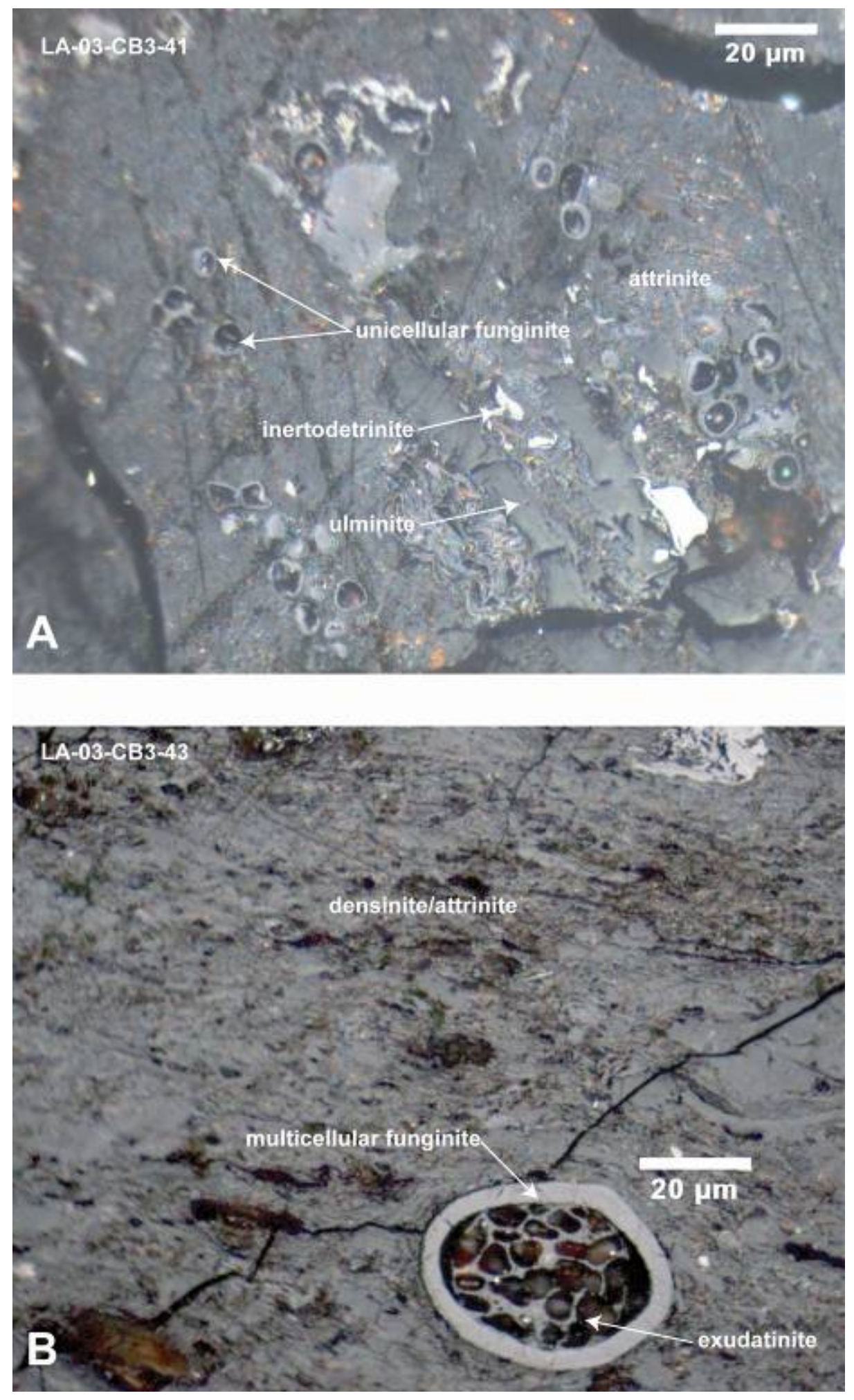

Figure 9. (A) Unicellular funginite in sample LA-03-CB3-41, oil immersion, reflected white light, (B) Multicellular funginite in sample LA-03-CB3-43, cells filled with exsudatinite, oil immersion, reflected white light. 

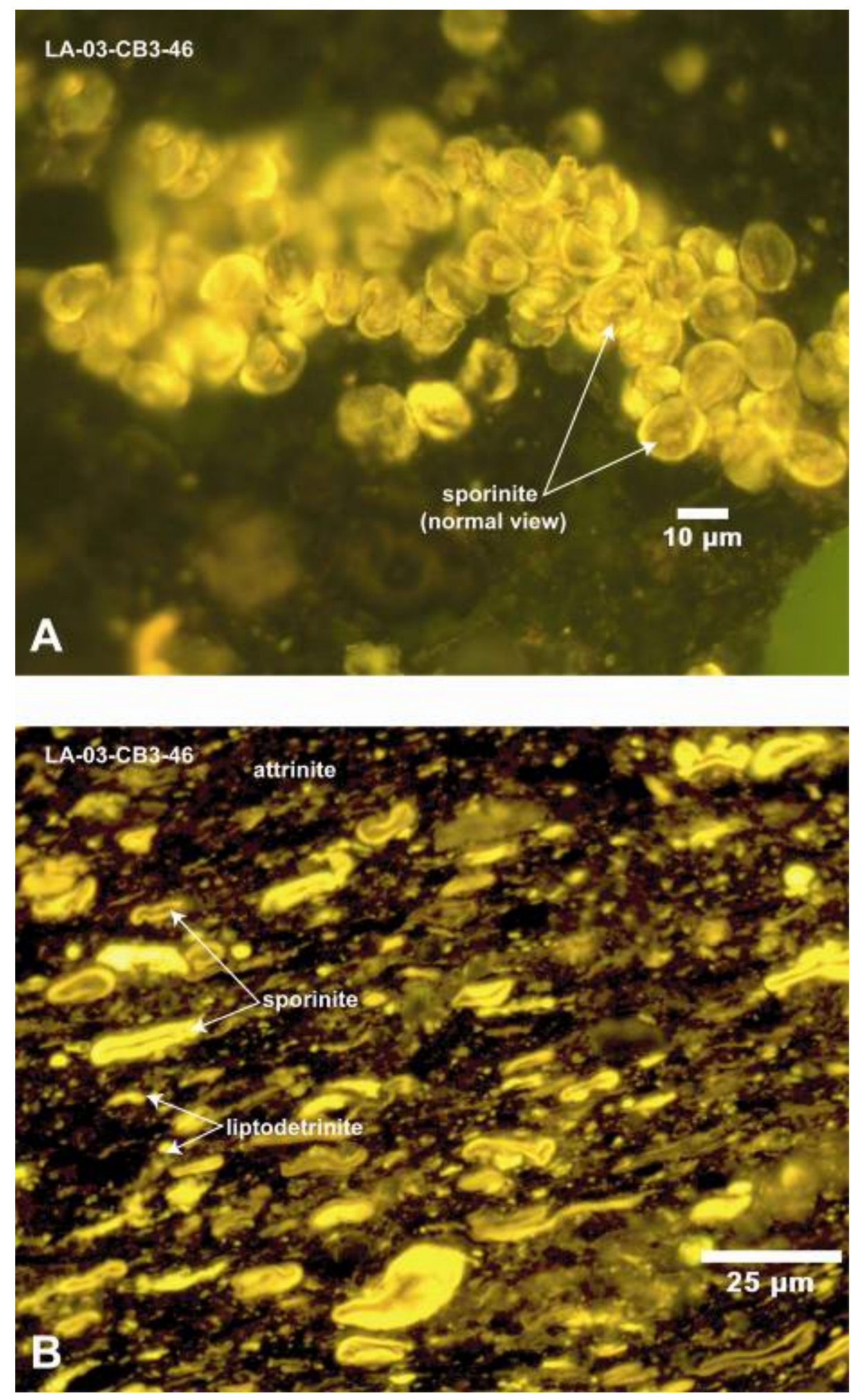

Figure 10. (A) Agglomeration of sporinite (view normal to bedding plane) in sample LA-03-CB3-46, air objective, reflected blue light, (B) Attrinite with sporinite and liptodetrinite in sample LA-03-CB3-46, air objective, reflected blue light. 

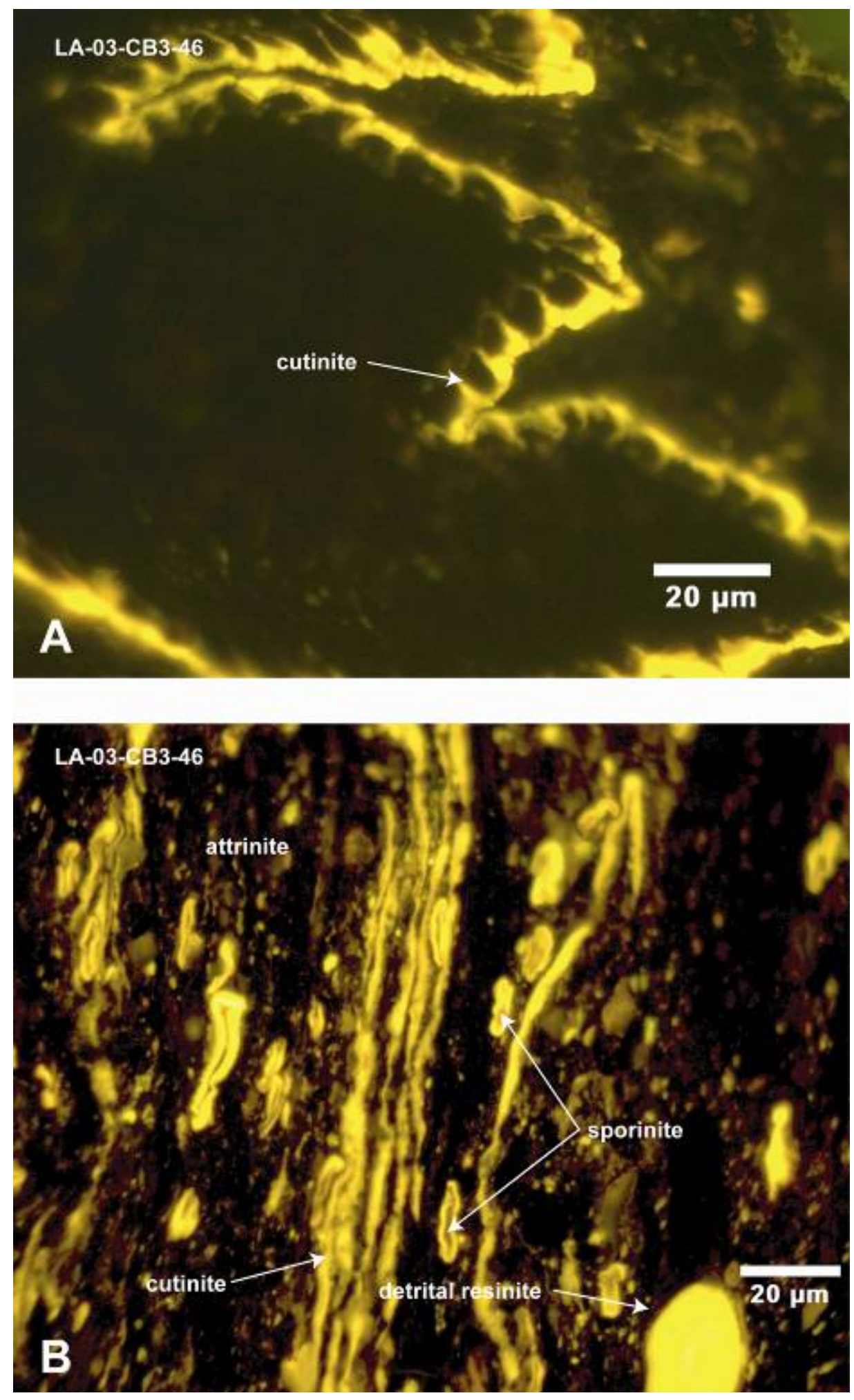

Figure 11. (A) Cutinite in sample LA-03-CB3-46, air objective, reflected blue light, (B) Attrinite, cutinite, sporinite, and detrital resinite in sample LA-03-CB3-46, air objective, reflected blue light. 
Table 1. Depth interval, sample identification, and stratigraphy of coal zones, FRE №. 359 coalbed methane test well.

\begin{tabular}{|c|c|c|c|}
\hline Depth Interval (ft) & Sample & Stratigraphy and Coal Z & \\
\hline $390-400$ & $390-400$ & \multirow{5}{*}{ Sparta Sand samples } & \\
\hline $420-430$ & $420-430$ & & \\
\hline $540-550$ & $540-550$ & & \\
\hline $650-660$ & $650-660$ & & \\
\hline $720-730$ & $720-730$ & & \\
\hline $1,329-1,330$ & LA-03-CB3-40 & \multirow{6}{*}{ Coal Zone 1} & \multirow{17}{*}{$\begin{array}{l}\text { Wilcox } \\
\text { samples }\end{array}$} \\
\hline 1,330-1,331 & LA-03-CB3-41 & & \\
\hline $1,331-1,332$ & LA-03-CB3-42 & & \\
\hline $1,332-1,333$ & LA-03-CB3-43 & & \\
\hline 1,333-1,334 & LA-03-CB3-44 & & \\
\hline 1,334-1,334.8 & LA-03-CB3-45 & & \\
\hline $1,498-1,498.9$ & LA-03-CB3-46 & \multirow{2}{*}{ Coal Zone 2} & \\
\hline 1,498.9-1,499.25 & LA-03-CB3-8 & & \\
\hline 1,515.25-1,515.5 & LA-03-CB3-10 & \multirow{3}{*}{ Coal Zone 3} & \\
\hline $1,516-1,516.9$ & LA-03-CB3-47 & & \\
\hline 1,516.9-1,517.5 & LA-03-CB3-9 & & \\
\hline 1,563.8-1,564.55 & LA-03-CB3-48 & stray coal & \\
\hline 1,574-1,574.9 & LA-03-CB3-49 & \multirow{5}{*}{ Coal Zone 4} & \\
\hline 1,575.8-1,576.8 & LA-03-CB3-50 & & \\
\hline 1,576.8-1,577.8 & LA-03-CB3-51 & & \\
\hline 1,579.2-1,580.2 & LA-03-CB3-52 & & \\
\hline $1,580.2-1,581.2$ & LA-03-CB3-53 & & \\
\hline
\end{tabular}


Table 2. Organic petrography and maximum reflectance of huminite $\left(R_{\max }\right)$ of Wilcox samples on vol.\% mmf basis, FRE No. 359 coalbed methane test well.

\begin{tabular}{|c|c|c|c|c|c|c|c|c|c|c|c|c|c|c|c|c|c|}
\hline SAMPLE & $\begin{array}{l}\text { LA-03- } \\
\text { CB3-40 }\end{array}$ & $\begin{array}{l}\text { LA-03- } \\
\text { CB3-41 }\end{array}$ & $\begin{array}{l}\text { LA-03- } \\
\text { CB3-42 }\end{array}$ & $\begin{array}{l}\text { LA-03- } \\
\text { CB3-43 }\end{array}$ & $\begin{array}{l}\text { LA-03- } \\
\text { CB3-44 }\end{array}$ & $\begin{array}{l}\text { LA-03- } \\
\text { CB3-45 }\end{array}$ & $\begin{array}{l}\text { LA-03- } \\
\text { CB3-46 }\end{array}$ & $\begin{array}{l}\text { LA-03- } \\
\text { CB3-8 }\end{array}$ & $\begin{array}{l}\text { LA-03- } \\
\text { CB3-10 }\end{array}$ & $\begin{array}{l}\text { LA-03- } \\
\text { CB3-47 }\end{array}$ & $\begin{array}{l}\text { LA-03- } \\
\text { CB3-9 }\end{array}$ & $\begin{array}{l}\text { LA-03- } \\
\text { CB3-48 }\end{array}$ & $\begin{array}{l}\text { LA-03- } \\
\text { CB3-49 }\end{array}$ & $\begin{array}{l}\text { LA-03- } \\
\text { CB3-50 }\end{array}$ & $\begin{array}{l}\text { LA-03- } \\
\text { CB3-51 }\end{array}$ & $\begin{array}{l}\text { LA-03- } \\
\text { CB3-52 }\end{array}$ & $\begin{array}{l}\text { LA-03- } \\
\text { CB3-53 }\end{array}$ \\
\hline $\mathbf{R}_{\max }$ & 0.36 & 0.37 & 0.36 & 0.38 & 0.38 & 0.33 & 0.39 & 0.22 & 0.35 & 0.33 & 0.35 & 0.35 & 0.39 & 0.34 & 0.36 & 0.35 & 0.30 \\
\hline No. measurements & 100 & 100 & 100 & 100 & 100 & 100 & 100 & 21 & 50 & 100 & 100 & 100 & 100 & 100 & 100 & 100 & 100 \\
\hline standard deviation & 0.05 & 0.03 & 0.04 & 0.03 & 0.03 & 0.03 & 0.03 & 0.05 & 0.03 & 0.05 & 0.04 & 0.04 & 0.04 & 0.05 & 0.05 & 0.04 & 0.04 \\
\hline HUMINITE (total) & 79 & 81 & 83 & 90 & 90 & 89 & 81 & 84 & 87 & 83 & 87 & 79 & 82 & 74 & 85 & 74 & 78 \\
\hline textinite & 1 & 1 & tr & 1 & 1 & 1 & 1 & $x$ & tr & 1 & 1 & 1 & 1 & $\mathrm{tr}$ & 1 & 1 & tr \\
\hline ulminite & 31 & 46 & 59 & 78 & 66 & 63 & 57 & 41 & 54 & 35 & 17 & 18 & 31 & 21 & 51 & 23 & 20 \\
\hline attrinite & 41 & 29 & 21 & 7 & 21 & 23 & 21 & 43 & 31 & 45 & 68 & 58 & 48 & 51 & 32 & 46 & 55 \\
\hline densinite & 2 & 1 & 1 & $x$ & $x$ & $\operatorname{tr}$ & $\operatorname{tr}$ & $\operatorname{tr}$ & 1 & $\operatorname{tr}$ & $\operatorname{tr}$ & $\operatorname{tr}$ & $\operatorname{tr}$ & $\mathrm{tr}$ & $\operatorname{tr}$ & $\operatorname{tr}$ & $\operatorname{tr}$ \\
\hline corpohuminite & 3 & 2 & 1 & $\operatorname{tr}$ & 2 & 1 & 1 & $\operatorname{tr}$ & 1 & 1 & 2 & 1 & 1 & 1 & 1 & 2 & 1 \\
\hline phlobaphinite & $\operatorname{tr}$ & 1 & 1 & 4 & 1 & 2 & 2 & $x$ & 1 & 1 & tr & tr & tr & $\operatorname{tr}$ & 1 & 1 & tr \\
\hline INERTINITE (total) & 13 & 14 & 8 & 2 & 4 & 5 & 3 & 15 & 6 & 3 & 2 & 2 & 9 & 14 & 5 & 8 & 9 \\
\hline fusinite & 2 & 5 & 2 & 1 & 1 & 2 & 1 & tr & 2 & 1 & tr & 1 & 2 & 4 & 2 & 2 & 1 \\
\hline semifusinite & 4 & 3 & 2 & tr & tr & 1 & tr & tr & tr & 1 & tr & tr & tr & 3 & 1 & 1 & tr \\
\hline macrinite & 3 & 2 & 2 & $x$ & tr & 1 & tr & 13 & 1 & 1 & 1 & 1 & 3 & 4 & 1 & 3 & 5 \\
\hline funginite & $\operatorname{tr}$ & $\operatorname{tr}$ & $\operatorname{tr}$ & tr & tr & $\operatorname{tr}$ & 1 & $x$ & $\operatorname{tr}$ & $\operatorname{tr}$ & tr & tr & tr & $\operatorname{tr}$ & tr & $\operatorname{tr}$ & tr \\
\hline inertodetrinite & 3 & 4 & 1 & tr & 2 & 2 & tr & 2 & 3 & 1 & tr & tr & 4 & 3 & 1 & 2 & 3 \\
\hline LIPTINITE (total) & 9 & 5 & 11 & 8 & 6 & 5 & 16 & 1 & 7 & 13 & 10 & 20 & 9 & 13 & 9 & 19 & 14 \\
\hline sporinite & 3 & 2 & 1 & 2 & 1 & 1 & 3 & tr & tr & 2 & 2 & 2 & tr & 3 & 1 & 1 & 1 \\
\hline cutinite & tr & $\operatorname{tr}$ & 1 & 1 & tr & tr & $\operatorname{tr}$ & 1 & $\operatorname{tr}$ & $\operatorname{tr}$ & tr & tr & $\operatorname{tr}$ & 1 & tr & $\operatorname{tr}$ & $x$ \\
\hline resinite in textinite & tr & $\operatorname{tr}$ & tr & tr & $\operatorname{tr}$ & $x$ & tr & $x$ & $x$ & tr & tr & tr & $x$ & 1 & $\operatorname{tr}$ & tr & $x$ \\
\hline resinite in matrix & $\operatorname{tr}$ & $\operatorname{tr}$ & 2 & 1 & 1 & 1 & 1 & tr & 1 & 1 & 1 & 2 & 1 & 1 & 1 & 1 & 2 \\
\hline bituminite & 1 & 1 & 1 & $x$ & tr & $x$ & 2 & $x$ & $x$ & $x$ & $x$ & 1 & 1 & tr & 3 & 5 & 2 \\
\hline exsudatinite & $x$ & tr & 1 & 1 & tr & tr & $x$ & tr & 1 & $\operatorname{tr}$ & 1 & $x$ & tr & 1 & tr & 1 & tr \\
\hline exsudatinite in funginite & $x$ & tr & $\operatorname{tr}$ & tr & $x$ & $x$ & $\operatorname{tr}$ & $x$ & $x$ & $\operatorname{tr}$ & $x$ & tr & $x$ & $\operatorname{tr}$ & tr & tr & tr \\
\hline alginite & 2 & 1 & 2 & 1 & 1 & 1 & 4 & tr & 1 & 3 & 4 & 4 & 2 & 2 & 1 & 2 & 1 \\
\hline liptodetrinite & 3 & 2 & 3 & 2 & 2 & 2 & 6 & $\operatorname{tr}$ & 4 & 6 & 3 & 10 & 5 & 4 & 3 & 8 & 7 \\
\hline vol. \% Mineral Matter & 5 & 6 & 4 & 5 & 12 & 14 & 11 & 55 & 7 & 7 & 22 & 37 & 23 & 5 & 7 & 7 & 15 \\
\hline
\end{tabular}


Table 3. Organic petrography and maximum reflectance of huminite $\left(\mathrm{R}_{\max }\right)$ of Sparta Sand coal cuttings on vol. \% mmf basis, FRE No. 359 coalbed methane test well.

SAMPLE

$\mathbf{R}_{\max }$

No. measurements

standard deviation

HUMINITE (total)

textinite

ulminite

attrinite

densinite

corpohuminite

phlobaphinite

INERTINITE (total)

fusinite

semifusinite

macrinite

funginite

inertodetrinite

\begin{tabular}{lccccc} 
LIPTINITE (total) & 19 & 6 & 8 & 23 & 24 \\
sporinite & 2 & 1 & 3 & 5 & 5 \\
cutinite & 1 & $\mathrm{tr}$ & $\mathrm{tr}$ & 1 & 1 \\
resinite in textinite & $\mathrm{tr}$ & $\mathrm{X}$ & $\mathrm{tr}$ & $\mathrm{tr}$ & $\mathrm{tr}$ \\
resinite in matrix & 5 & 3 & 2 & 7 & 7 \\
bituminite & 1 & $\mathrm{X}$ & $\mathrm{X}$ & $\mathrm{tr}$ & $\mathrm{tr}$ \\
exsudatinite & 1 & 1 & $\mathrm{tr}$ & $\mathrm{tr}$ & $\mathrm{tr}$ \\
exsudatinite in funginite & $\mathrm{X}$ & $\mathrm{tr}$ & $\mathrm{X}$ & $\mathrm{X}$ & $\mathrm{X}$ \\
alginite & 2 & $\mathrm{tr}$ & $\mathrm{tr}$ & 2 & 2 \\
suberinite & $\mathrm{X}$ & $\mathrm{X}$ & $\mathrm{tr}$ & $\mathrm{X}$ & $\mathrm{X}$ \\
liptodetrinite & 7 & 2 & 3 & 10 & 10 \\
& & & & & \\
Vol.\% Mineral Matter & 28 & 9 & 18 & 62 & 66 \\
\hline
\end{tabular}

$\mathrm{X}=$ not present, tr=present in quantities $<1 \mathrm{vol} . \%$, Vol.\% Mineral Matter determined by point count.

\section{$390-400 \quad 420-430 \quad 540-550 \quad 650-660 \quad 720-730$}

$\begin{array}{lllll}0.29 & 0.36 & 0.34 & 0.35 & 0.37 \\ 100 & 100 & 100 & 100 & 100 \\ 0.04 & 0.04 & 0.04 & 0.06 & 0.06\end{array}$

$\begin{array}{lllll}80 & 93 & 88 & 73 & 74\end{array}$

$\begin{array}{lllll}1 & 1 & 1 & \text { tr } & 1\end{array}$

$\begin{array}{lllll}28 & 59 & 39 & 12 & 23\end{array}$

$\begin{array}{lllll}46 & 28 & 40 & 56 & 48\end{array}$

tr tr tr tr tr

$\begin{array}{lll}4 & 1 & 4\end{array}$

$1-5$

$1 \quad$ tr

$x \quad x$

$x \quad x$

$X \quad$ tr

$1 \quad$ tr

$x \quad x$

1

1

tr

$\operatorname{tr}$

$x$

1

X

$\begin{array}{cc}1 & \text { tr } \\ \operatorname{tr} & \mathrm{X} \\ \mathrm{X} & \mathrm{X} \\ \mathrm{tr} & \mathrm{tr} \\ 1 & \mathrm{tr} \\ \mathrm{X} & \mathrm{tr}\end{array}$

